\title{
TRIXACARUS CAVIAE FAIN, HOWELL \& HYATT 1972 (ACARI: SARCOPTIDAE) AS A CAUSE OF MANGE IN GUINEA-PIGS AND PAPULAR URTICARIA IN MAN
}

\section{G.M. DORRESTEIN and J.E.M.H. VAN BRONSWIJK}

Department of Special Animal Pathology, Faculty of Veterinary Medicine, and Laboratory of Microbiology, Institute of Dermatology, Faculty of Medicine, State University, Utrecht (The Netherlands)

(Accepted 25 April 1979)

\section{ABSTRACT}

Dorrestein, G.M. and Van Bronswijk, J.E.M.H., 1979. Trixacarus caviae Fain, Howell $\&$ Hyatt 1972 (Acari: Sarcoptidae) as a cause of mange in guinea-pigs and papular urticaria in man. Vet. Parasitol., 5: 389-398.

The clinical symptoms of infestation with Trixacarus caviae in guinea-pigs are described. In general large areas of thickened, denuded skin, with a heavy secondary bacterial infection, and sometimes neurological signs, are observed in mangy cases. Antiparasitic therapy was successful with one or several washings with $0.15 \%$ trichlorphon or $0.07 \%$ lindane solutions.

Histological examination of the skin of mangy guinea-pigs revealed acanthosis, pronounced thickening of the epidermis and increased indentations of the cutis. The mites were embedded in epidermal debris in the folds of the skin. They were often found in the superficial part of the hair follicles. Inflammation of the subcutis was pronounced.

Healthy guinea-pigs developed mild signs of mange approximately 10 days after exposure by skin contact to heavily infested animals. These experimentally infested guineapigs recovered without treatment. An itching papular urticarial condition in three human patients was found associated with trixacariasis of guinea-pigs. The lesions were usually located on the skin areas in frequent contact with the infected animals. This human affliction cleared after terminating contact with the mangy pig or after antiparasitic treatment of the animal.

\section{INTRODUCTION}

Mange in domestic animals is often caused by the itch mite Sarcoptes scabiei (L. 1758). In fact, Fain proposed the hypothesis that $S$. scabiei was at first an ectoparasite of only Homo sapiens and in the course of history man had infested all his newly domesticated mammals. Only the cat seemed to have escaped the affliction (Fain, 1968). Before 1972 mange in guinea-pigs was attributed only to Sarcoptes scabiei and Notoedres muris (Neveu-Lemaire, 1938; Soerensen et al., 1963; Ronald and Wagner, 1976). Sarcoptic mange was described as being rare, usually extensive and severe, and found in most 
countries of Europe. Notoedric mange was supposed to be limited to the head area of the animal and was less severe.

In 1972 Fain and associates described a new sarcoptid mite of the guineapig: Trixacarus caviae. Another case was described 4 years later (BeresfordJones et al., 1976). A preliminary survey of mangy guinea-pigs in The Netherlands revealed only $T$. caviae as the causal sarcoptiform mite (Dorrestein and Van Bronswijk, 1977).

This paper, on the basis of Dutch material, deals with the identity, infectivity and habits of mites of guinea-pigs which produce a disease similar to sarcoptic mange in other animals.

\section{MATERIALS AND METHODS}

(a) Seventeen mangy guinea-pigs were examined during the period January 1976 to July 1977 by one of the authors (G.M.D.). Deep scrapings were made and the material was mixed with either $10 \% \mathrm{KOH}$ or chlorallactophenol, and warmed slightly. In this way the skin material of the host became transparent and the mites could be detected under a compound light microscope. Usually some of the infested material was stored in ethanol $70 \%$ to which $10 \%$ $(w: w)$ glycerol was added. Permanent mountings of the mites were made in Hoyers' medium (Krantz, 1971). Specific identification of the mites was performed by one of the investigators (J.E.M.H. v. B.). The owners of the infested guinea-pigs were asked when the symptoms had started and if there was any human involvement.

Six of the infested guinea-pigs could be studied while still alive, five of these were treated and one was used for experimentation. The other animals had been killed before being sent in or were treated at home. Of the five animals treated, one was given orally fenchlorphos $\left(\right.$ Ectoral $^{\circledR}$; Laboratoria Nobilis N.V.) for 21 days and four were washed with $0.07 \%$ lindane (Neoscabexan ${ }^{\circledR}$, containing $7 \%$ lindane; Gist-Brocades N.V.).

(b) Skin biopsies were taken from four cases to study the spatial relationships of the mites and the reaction in the host tissue. After fixation of the skin biopsy in $10 \%$ buffered formalin, sections ( $7 \mu \mathrm{m}$ thick) were made and stained with hematoxylin and eosin.

(c) The severely mangy guinea-pig was put in one cage with two healthy ones. During the following 6 weeks the guinea-pigs were inspected daily for presence of any skin disease or change in behaviour. A volunteer petted the mangy guinea-pig every day for $5 \mathrm{~min}$ and reported on development of any urticaria or papules.

After 5 days the mangy guinea-pig died and was removed from the cage. Once every week the remaining guinea-pigs were photographed and then vacuum cleaned for $5 \mathrm{~min}$. The dust samples were examined for the presence of arthropods, using a flotation method (Van Bronswijk, 1973). Biopsies 
were also taken and treated as above. Three weeks after their first contact with the mangy guinea-pig both animals were put in the same cage with two other healthy guinea-pigs for 5 days. Similarly two other guinea-pigs were placed with the last two mentioned guinea-pigs. Seven weeks after their first contact with the original infested guinea-pig, the guinea-pigs exposed received antiparasitic therapy (washing with $0.15 \%$ trichlorphon; [dimethyl $(2,2,2-$ trichloro-1-hydroxyethyl)-phosphonate] Neguvon $^{\circledR}$ ).

\section{RESULTS}

(a) Trixacarus caviae was the only species of sarcoptiform mange mite detected. In 11 of the 17 cases, immature stages (nymphs and larvae) were more numerous than adults in the material studied. The age of the affected guineapigs varied from 3 months to more than 4 years, but the most common age was from 1 to 3 years (70\%). The mangy guinea-pigs originated from five of the 11 Dutch provinces. The clinical picture of the infested animals included severe itching, scratch marks, and mange. The owners were generally most alarmed by the so-called 'fits'. Upon touching, the guinea-pig would react with muscular spasms, especially of the legs. Seriously affected guinea-pigs were often in poor condition. They had visible mange lesions which had developed during the 2 or 3 previous weeks.

The affected areas of the skin were more or less denuded, very red and often thickened and wrinkled. The tops of the wrinkles were sometimes covered with thick crusts, greyish-white to dark grey in colour. Often the crusts were greasy, sometimes dry. The lesions were exceedingly irritating and caused much biting and scratching. Fresh wounds and older scars were generally numerous (Fig. 1). The denuding of the skin was caused both by the excessive loss of hair, and the breaking of the hair as a result of biting and scratching. All parts of the body eventually became affected. Infestation usually started on the face, ears, at the sacral region and outside of the legs. Mites were most easily detected in skin scrapings from areas covered with crusts but not yet deeply scratched.

Three owners of infested guinea-pigs reported that they themselves developed an 'itch' after contact with the animals. Dermatological investigation of these patients was not feasible, but papules were reported.

Antiparasitic treatment of the guinea-pigs was generally successful. An effective remedy was $0.07 \%$ lindane, applied as washings repeated on the fourth day and then once a week until the symptoms disappeared. In all cases the skin appeared normal after 3-4 weeks. Restoration of the normal coat took 2 more weeks. An oral treatment with fenchlorphos in a dose of $25 \mathrm{mg} / \mathrm{kg}$ bodyweight for 21 days, also cured the infestation, but more slowly. A wash with $0.15 \%$ trichlorphon resulted in a complete cure within 7 days, but the two guinea-pigs treated with this material had only light infestations. 

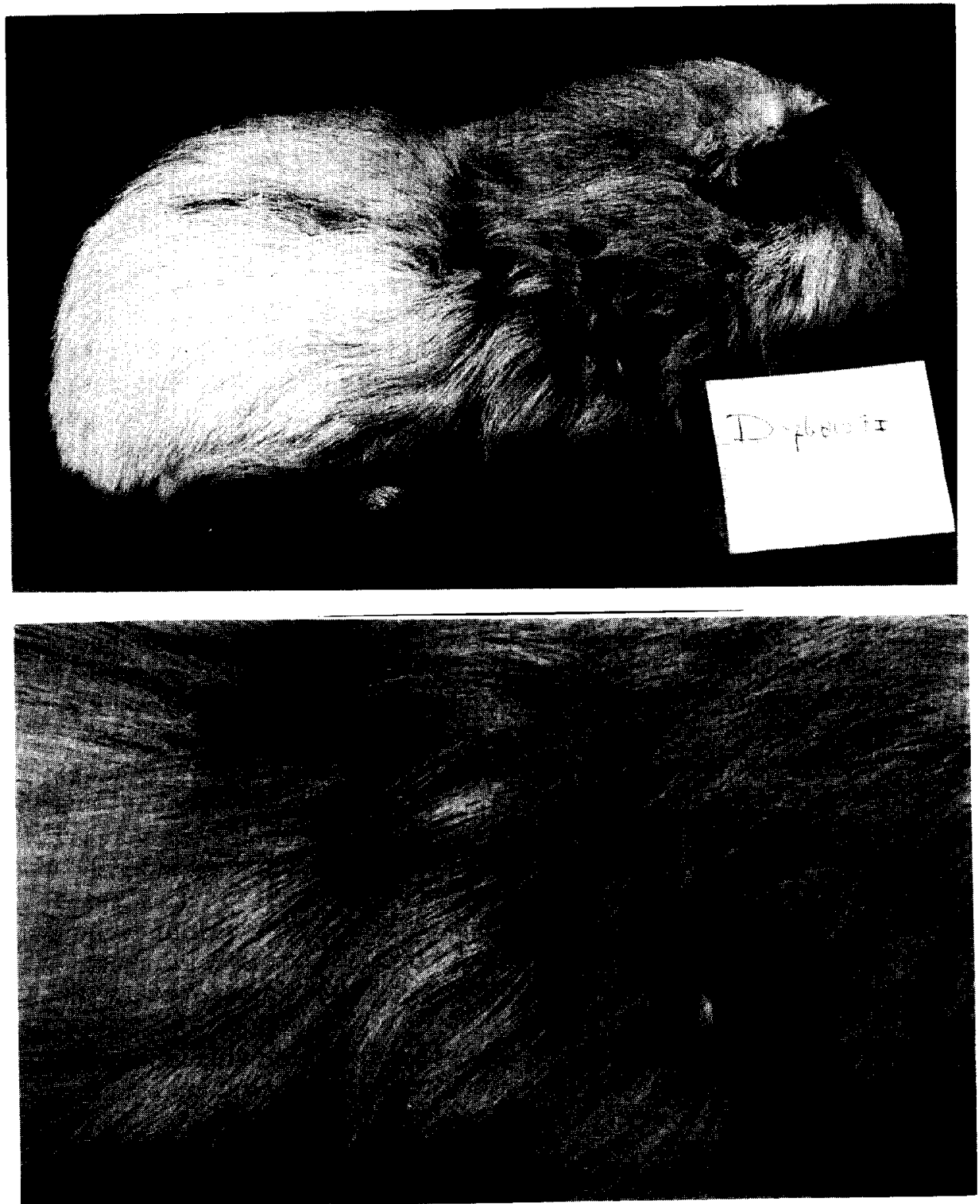

Fig. 1. Severe mange in a guinea-pig. A. General view. B. Detail near the foreleg.

(b) The histological pictures of the four biopsies were similar. Hyperkeratosis was pronounced and acanthosis caused by thickening of the stratum spinosum was obvious. The inflammation in the dermis and hypodermis consisted predominantly of an infiltration of polymorphonuclear leucocytes. The ridges and papillae of the papillary layer were increased in number and the stratum germanitivum was highly wrinkled. 
Increase in the size of the capillaries indicative of hyperaemia was visible in the dermis. The mites could be found in the enlarged hair follicles (Fig. 2) and in the stratum corneum. The parasites in the follicles were enveloped by a layer of keratinized epidermal cells and detritus, and remained in small caverns. These mite-containing caverns were apparently pushed out of the follicles to end in the stratum corneum through growth of the hair. Not only mites but also mite eggs and brown-black staining excreta were found in the caverns. In severely infested skin areas the number of hair follicles seemed to be decreased. There was no evidence of active penetration of the stratum granulosum by the mite.

(c) The mites collected with the vacuum cleaner during the transmission experiments are listed in Table I. Two species were present: Chirodiscoides caviae and Trixacarus caviae. The latter species was found only on guinea-pigs after contact with mangy animals. In the first series of exposure this transmission occurred after 1 week of contact and in the second series it was after 4 weeks of contact. In addition, lice and nits (eggs) were found on three guinea-pigs (IIb, IIIa and IIIb). The species of louse was identified as Gliricola porcelli. Two types of nits were present, one had sculptured and the other smooth

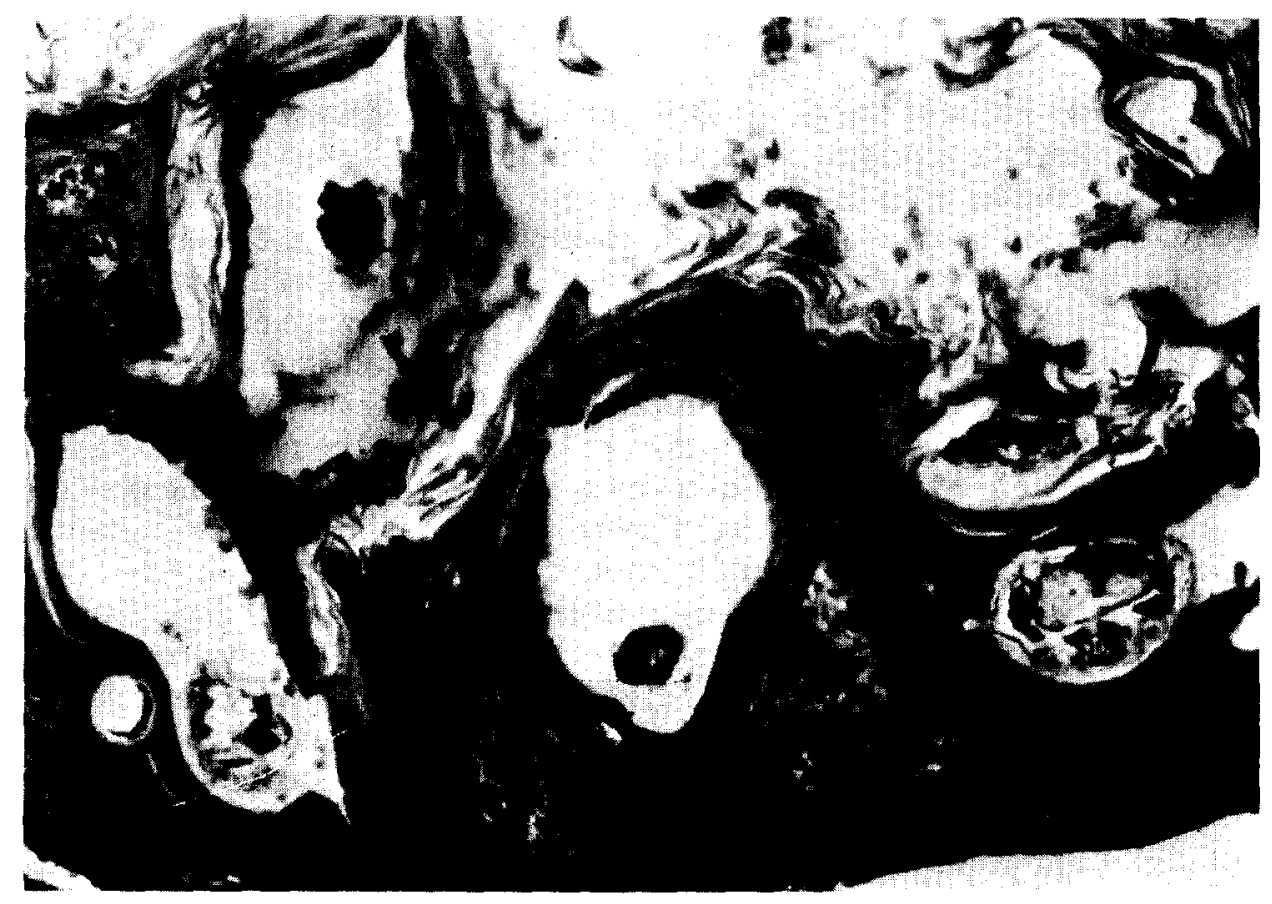

Fig. 2. Skin changes in biopsy material. Notice acanthosis, hyperkeratosis, inflammation in the subcutis, and mites in hair follicles and stratum corneum, surrounded by a layer of debris (HE $100 \times$ ). 


\section{TABLE I}

Parasitic mites found in the dust samples from the guinea-pigs in the transmission experiments

\begin{tabular}{|c|c|c|c|c|c|}
\hline \multirow[t]{3}{*}{ Guinea-pig } & \multirow{3}{*}{$\begin{array}{l}\text { Weeks } \\
\text { after } \\
\text { exposure }\end{array}$} & \multicolumn{4}{|c|}{ Number of mites isolated } \\
\hline & & \multicolumn{2}{|c|}{ Chirodiscoides caviae } & \multicolumn{2}{|c|}{ Trixacarus caviae } \\
\hline & & Adult & Immature & Adult & Immature \\
\hline \multirow[t]{2}{*}{$I^{*}$} & 0 & 0 & 0 & 1 & 2 \\
\hline & 1 & 1 & 0 & 5 & 8 \\
\hline \multirow[t]{3}{*}{ IIa } & 0 & 0 & 1 & 0 & 0 \\
\hline & 1 & 0 & 0 & 0 & 1 \\
\hline & 3 & 0 & 1 & 0 & 0 \\
\hline IIb & 0 & 1 & 1 & 0 & 0 \\
\hline \multirow[t]{2}{*}{ IIIa } & 0 & 2 & 8 & 0 & 0 \\
\hline & 1 & 0 & 1 & 0 & 0 \\
\hline \multirow[t]{4}{*}{ IIIb } & 0 & 8 & 11 & 0 & 0 \\
\hline & 1 & 0 & 1 & 0 & 0 \\
\hline & 3 & 0 & 1 & 0 & 0 \\
\hline & 4 & 0 & 0 & 1 & 1 \\
\hline
\end{tabular}

*This guinea-pig was presented with serious mange and unknown history.

shells. Forage mites of the genera Glycyphagus and Acarus were identified in a dust sample from one guinea-pig (IIb). The first two guinea-pigs (IIa and IIb) brought in contact with the mangy guinea-pig (I) became somewhat restless 9 days after contact, and started to scratch more frequently. Eleven days after contact, bald scaly patches become visible. Scratching was at its maximum 11-15 days after the initial exposure. The scaly lesions were never more than $1-2 \mathrm{~cm}$ in diameter. Twenty-three days after infestation skin lesions began to regress. However, 4 weeks post-infestation neurological symptoms developed. One week later the guinea-pigs were treated with the parasiticide trichlorphon. The second series of exposed guinea-pigs stayed with the previously infested guinea-pigs for 15 days. Three days after exposure they started to scratch. A bald scaly patch, about $1 \mathrm{~cm}$ in diameter, developed on each guinea-pig 8-10 days after exposure. The lesion did not spread and itching was apparently not very annoying since no serious scratching occurred. By the end of this experiment, 5 weeks after contact, the bald scaly patches were still present but the animals did not show discomfort. Mites, eggs, or excreta were never found in the histological preparations of the weekly biopsy material of the back, lateral to the dorsal midline, nor were the above-mentioned caverns present. Slight acanthosis and hyperkeratosis, and mild infiltration of polymorphonuclear leucocytes were all that could be observed.

After petting the severely affected guinea-pig (I) the technician developed small papules on the bare arm which supported the guinea-pig (Fig. 3). The papules occurred 2 days after the onset of the experiment, and vanished 


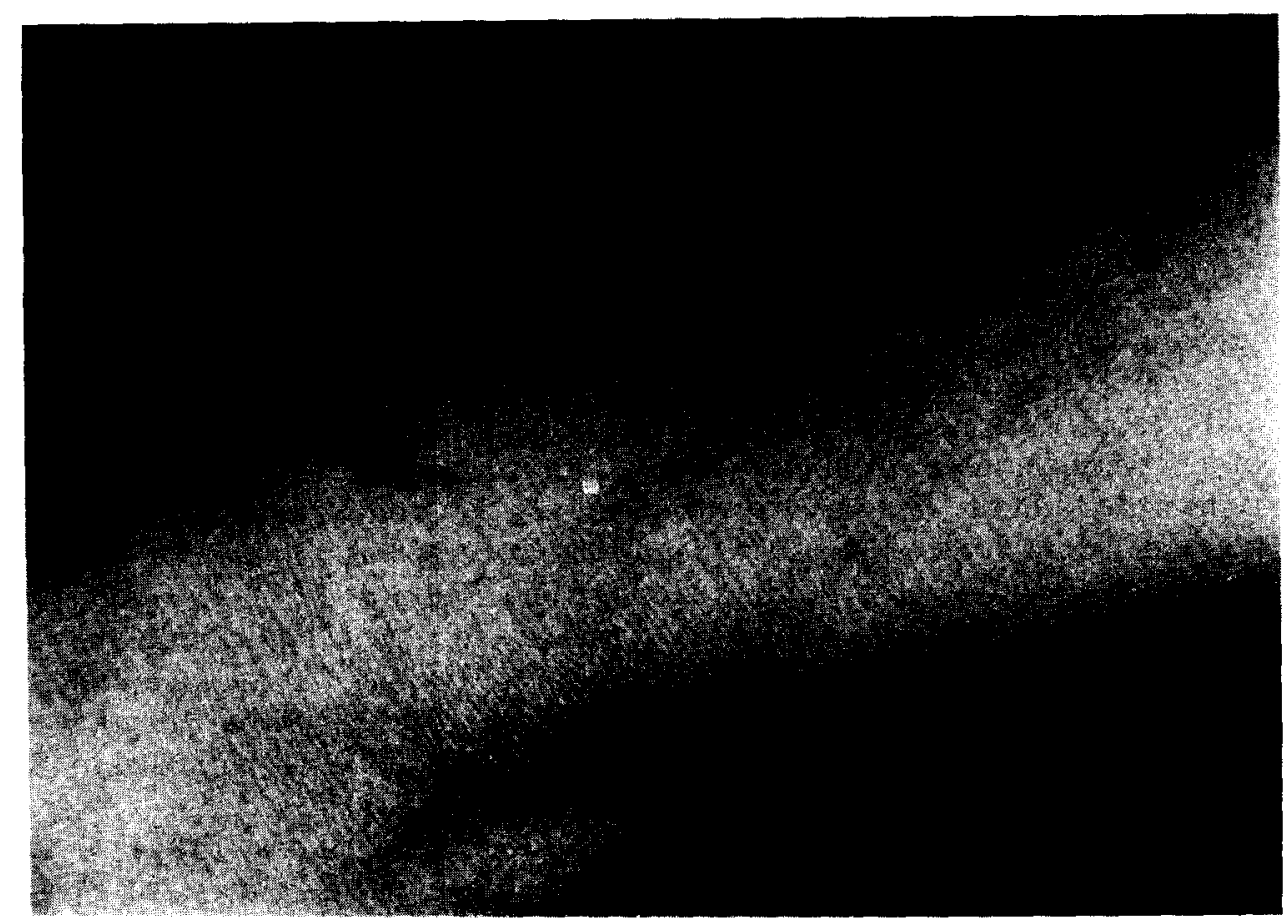

Fig. 3. Papular urticaria on the arm of the technician after petting an infested guinea-pig.

3 days after the last contact with the guinea-pig. Itching was moderate, and no skin symptoms developed after petting the more lightly infested guineapig.

\section{DISCUSSION}

T. caviae is the only mange mite found on mangy guinea-pigs in The Netherlands in this study. Infestations with mites such as Myocoptes musculinis of mice, Notoedres muris of rats and Sarcoptes scabiei of rabbits (Rigby, 1976), were not seen and there was no report of intimate contact with these animals. Mange of guinea-pigs, mentioned in older literature (Bosse, 1968), which had no contact with other mangy mammals, may have been caused by Trixacarus.

Trixacarus caviae has been found only on Cavia porcellus (Fain et al., 1972; Beresford-Jones et al., 1976; Sebesteny, 1976; Dorrestein and Van Bronswijk, 1977), and the other species of the genus, $T$. diversus, is known from Rattus norvegicus, $R$. rattus and Mesocricetus auratus (Sellnick, 1944; Guilhon, 1946a; Enigk and Grittner, 1951; Lavoipierre, 1960; Fain, 1968). Guilhon (1946a) was not able to raise it on guinea-pigs.

The clinical picture of severe mange we found agrees with earlier reports (Fain et al., 1972; Beresford-Jones et al., 1976) and the studies of $T$. diversus 
infections of other Rodentia (Guilhon, 1946b; Enigk and Grittner, 1951).

Diagnosis is best achieved by microscopic study of deep skin scrapings in $10 \% \mathrm{KOH}$. Examination of dust samples from the fur of the animals gives too low numbers of parasites. Under the microscope, discrimination between Sarcoptes scabiei and Notoedres muris is not particularly difficult (Dorrestein and Van Bronswijk, 1977).

Treatment was accomplished by washing with a trichlorphon or lindane preparation. We prefer trichlorphon because it is a less persisting antiparasiticum (Werkgroep Anti-ectoparasitica, 1978). Infected cages should be cleaned and treated with the same solution. It is probably best to leave the cages and other utensils unused for about 3 weeks (Soulsby, 1969). Lindane preparations were found to be useful by others in cases of sarcoptid mange in guineapigs (Beresford-Jones et al., 1976), and some success was obtained by bathing the animals in a tetraethylthiuram monosulfide $\left(\right.$ Tetmosol $^{\circledR}$, I.C.I.) (Fain et al., 1972). In more severe cases it was necessary to repeat the washing once a week for $4-8$ weeks, either with trichlorphon or lindane. To treat a colony, good results were obtained with a dichlorvos-vapor-box, exposed 1 day a week for 6 weeks. It seems advisable to wash the mangy guinea-pigs with shampoo before starting the antiparasitic treatment (Dorrestein, 1977).

Poor rearing conditions were observed in some of the cases in the present investigations. Fain et al. (1972) stated that too high temperatures, sub-optimal ventilation, overcrowding and nutritional deficiencies were considered to be predisposing factors to the development of sarcoptid mange in guinea-pigs. It must be stressed therefore, that the living conditions of the diseased animals also should be improved, and care should be taken to incorporate sufficient vitamin $\mathrm{C}$ in the diet.

Some of these guinea-pigs had been in the possession of the owners for more than 2 years as the only pet and there had been no recent contact with other guinea-pigs. It is possible that some guinea-pigs are hosts to low numbers of Trixacarus mites which cause no, or almost no, discomfort, and only when the living conditions deteriorate, are the mites able to multiply rapidly and cause typical mange. In our transmission experiment a population of $T$. caviae developed on exposed guinea-pigs, but clinical signs of severe mange did not develop. The predisposing factors mentioned by Fain et al. (1972) were not present in our transmission experiment.

It is interesting that the histological picture indicated that $T$. caviae does not burrow as does Sarcoptes scabiei. T. diversus was reported by Guilhon (1946b) to dig burrows, but the histological picture he showed bears a great resemblance to the present findings. A number of species of the genus Notoedres (e.g. N. muris and $N$. schoutedeni) are also known to live in small caverns and not in burrows (Fain and Elsen, 1967).

Transient infestations of man with papular urticaria and itch are common with sarcoptic mites (Kutzer and Grünberg, 1969). T. diversus was reported to cause discomfort in man (Enigk and Grittner, 1951). The present results indicate that $T$. caviae has the same propensity. Bosse (1968) reported human 
involvement in "sarcoptic mange" of guinea-pigs, but specific identification of the mite was not made.

\section{ACKNOWLEDGEMENTS}

We are grateful to Mr. H.G. den Hartog and H. Vos for technical assistance, Dr. D. Gil, Central Animal Laboratory for housing the infected animals in the transmission experiments, Mr. G.C. de Graaf for preparing the histological slides, Dr. P. Zwart, Department of Special Animal Diseases and Dr. J.R. Hoffman, Michigan State University, East-Lansing, Michigan, U.S.A. for correcting the manuscript.

\section{REFERENCES}

Beresford-Jones, W.P., Fain, A. and Thoday, K.L., 1976. Further observations relating to Trixacarus (Caviacoptes) caviae Fain, Howell and Hyatt, 1972 in guinea-pigs (Acarina: Sarcoptidae). Acta Zool. Pathol. Antverpiensia, 64: 33-36.

Bosse, K., 1968. Die Hauterkrankungen des Meerschweinschens unter Berücksichtigung der Anthropozoonosen. Z. Versuchstierkd., 10: 62-74.

Dorrestein, G.M., 1977. Huidparasieten bij cavia's. Avicultura, 91 (12): 19-21.

Dorrestein, G.M. and Van Bronswijk, J.E.M.H., 1977. Trixacarus schurft bij cavia's. Tijdschr. Diergeneeskd., 102: 748-753.

Enigk, K. and Grittner, I., 1951. Die Sarcoptesräude des Goldhamsters. Z. Parasitenkd., 15: 25-33.

Fain, A., 1968. Etude de la variabilité de Sarcoptes scabiei avec une revision des Sarcoptidae. Acta Zool. Pathol. Antverpiensia, 47: 3-196.

Fain, A. and Elsen, P., 1967. Les acariens de la famille Knemidokoptidae, producteurs de gale chez les oiseaux (Sarcoptiformes). Acta Zool. Pathol. Antverpiensia, 45: 21-22.

Fain, A., Howell, G.J.R. and Hyatt, K.H., 1972. A new sarcoptid mite producing mange in albino guinea-pigs. Acta Zool. Pathol. Antverpiensia, 56: 73-82.

Guilhon, J., 1946a. Un nouvel acarien parasite du rat blanc. Soc. Séances Acad. Sci., 223: 108-109.

Guilhon, J., 1946b. Une nouvelle affection cutanée du rat. Bull. Acad. Vét. France, 19: 285-296.

Kutzer, E. and Grünberg, W., 1969. Zur Frage der Uebertragung tierischer Sarcoptesräuden auf den Menschen. Berl. Münch. Tierärztl. Wochenschr., 82: 311-314.

Krantz, G.W., 1971. A Manual of Acarology. Oregon State University Book Stores, Corvallis, 335 pp.

Lavoipierre, M.M.J., 1960. Notes acarologiques. II. Quelques remarques sur Trixacarus diversus Sellnick, 1944 (Sarcoptes anacanthos Guilhon 1946) et sur trois espèces récemment décrites de Sarcoptes des singes et des chauvesouris. Ann. Parasitol. Hum. Comp., 35: 166-170.

Neveu-Lemaire, M., 1938. Traité d'Entomologie Médicale et Vétérinaire. Vigot, Paris, 1339 pp.

Rigby, C., 1976. Natural infections of guinea-pigs. Laboratory Animals, 10: 119-142.

Ronald, N.C. and Wagner, J.E., 1976. The arthropod parasites of the genus Cavia. In: J.E. Wagner and P.J. Manning (Editors), The Biology of the Guinea Pig. Academic Press, New York, N.Y., pp. 201-208.

Sebesteny, A., 1976. Diseases of guinea-pigs. Vet. Rec., 98: 418-423.

Sellnick, M., 1944. Eine neue parasitische Milbe von Epimys norvegicus Erxl. Z. Parasitenkd., 13: 248-253. 
Soerensen, B., Saliba, A.M. and Neto, L.Z., 1963. Sarna em ratos e cobaios. Biológico, 29: $232-234$.

Soulsby, E.J.L., 1969. Helminths, Arthropods and Protozoa of Domesticated Animals, 6 th edition. Baillière, Tindall \& Cassell, London, $824 \mathrm{pp}$.

Van Bronswijk, J.E.M.H., 1973. Dermatophagoides pteronyssinus (Trouessart, 1897) in mattress and floor dust in a temperate climate (Acari: Pyroglyphidae). J. Med. Entomol. 10: $63-70$.

Werkgroep Anti-ectoparasitica, 1978. Anti-ectoparasitica. Dierg. Memorandum, 25: 77135. 